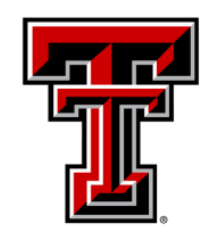

TEXAS TECH UNIVERSITY

Libraries"

\title{
WHERE HAVE ALL THE LEADERS GONE? EVALUATING THE DYNAMICS OF PARTIES' ISSUE ATTENTION IN COALITION GOVERNMENTS
}

\section{The Texas Tech community has made this publication openly available. Please share how this access benefits you. Your story matters to us.}

\begin{tabular}{|l|l|}
\hline Citation & $\begin{array}{l}\text { Sagarzazu, I. and Klüver, H. (2017), Where Have All the Leaders } \\
\text { Gone? Evaluating the Dynamics of Parties' Issue Attention in } \\
\text { Coalition Governments. Social Science Quarterly, 98: 1045-1060. } \\
\text { https://doi.org/10.1111/ssqu.12437 }\end{array}$ \\
\hline Citable Link & $\underline{\text { http://hdl.handle.net/2346/73268 }}$ \\
\hline Terms of Use & $\underline{\text { CC BY-NC }}$ \\
\hline
\end{tabular}


caption

\title{
Where have all the leaders gone? Evaluating the dynamics of parties' issue attention in coalition governments $^{1}$
}

\author{
Iñaki Sagarzazu \\ Texas Tech University \\ inaki.sagarzazu@ttu.edu \\ Heike Klüver \\ Humboldt University Berlin \\ heike.kluever@hu-berlin.de
}




\begin{abstract}
Objective: While selective issue emphasis is a widely recognized strategy of party competition, we have little knowledge about how coalition parties interact with each other when deciding which policy issues to emphasize. Therefore we ask, who leads and who follows the issue agenda in coalition governments?

Methods: We create an issue attention dataset using quantitative text analysis from over 40,000 press releases. We use this dataset and time-series cross-section regression analysis to study the dynamics of coalition parties' issue attention.

Results: We find that junior coalition parties are more responsive to their senior partners than senior partners to their junior partners. Hence, while coalition partners generally follow each other, senior partners enjoy a stronger leadership role in the cabinet.

Conclusion: Coalition parties indeed coordinate their issue priorities as they respond to each other's issue agenda. However, due the asymmetric power distribution in coalition cabinets, it is not a negotiation process on equal footing.
\end{abstract}




\section{Introduction}

Who leads and who follows the issue agenda in coalition governments? While selective issue emphasis is a widely recognized strategy of party competition (Budge and Farlie, 1983, Petrocik, 1996), we have little knowledge about how coalition parties interact with each other when deciding which policy issues to emphasize. Coalition cabinets composed of at least two different parties which share executive offices are the dominant form of government in European democracies (Andersson and Ersson, 2012). While coalition scholars have devoted considerable attention to government formation, cabinet governance and coalition duration (e.g. Bäck, Debus and Dumont, 2011, Müller and Meyer, 2010, Saalfeld, 2008, Strøm and Bergman, 2008), little is however known about how parties reconcile the tension between governing in coalitions and party competition. Since selective issue emphasis is an important instrument through which parties compete for voters, it is surprising that we hardly know anything about how coalition parties choose the policy issues they talk about (for an exception, see Sagarzazu and Klüver, forthcoming).This research gap is due, partly, to the difficulty in accessing and processing party communication. However, in the last couple of decades these limitations have been lifted allowing for a growing and rich literature studying political communication. In this paper, we seek to contribute to this literature by shedding light on who sets the issue agenda in coalition governments.

The dynamics of parties' issue attention has long been the focus of scholars of party competition and political communication. Proponents of issue ownership theory have argued that political parties primarily emphasize policy issues on which they have an advantage (Budge and Farlie, 1983 , Petrocik, 1996). Parties are considered to own certain issues as they are considered to be particularly competent at dealing with these issues. For instance, the US Democrats are typically considered to be competent at dealing with health care while the Republicans are trusted more when it comes to defence. According to the issue ownership theory, political parties have strategic incentives to emphasize the policy issues which they own to increase the salience of their favorable issues in the minds of voters (Bélanger and Meguid, 2008). By turning the election into a contest about their owned issues, political parties could reap electoral gains as voters would be likely to vote for the party they consider to be most competent at handling the most important issue of the day.

The riding the wave theory by contrast suggests that parties do not set the agenda, but that political parties instead respond to the issue priorities of voters (Ansolabehere and Iyengar, 1994). According to this theory, parties try to reap electoral gains by adhering to the issues of the day that are salient in the minds of their voters. Instead of seeming out of touch by not reacting to the concerns of their electorate, political parties would carefully monitor public opinion and strategically emphasize policy issues that are important to their voters. Recent empirical evidence accordingly shows that political parties respond to the issue priorities of their voters in their election manifestos (Klüver and Spoon, 2014 Spoon and 
Klüver, 2014, 2015, Wagner and Meyer, 2014) and in their day-to-day political communication (Klüver and Sagarzazu, 2016).

Party scholars have moreover argued that the competition between different political parties is an important factor that accounts for parties' issue attention. Importantly, the rise of policy issues was considered to be driven by parties that were disadvantaged by the dominant dimension of conflict in a party system. Carmines and Stimson $(1986,1989)$ have suggested that parties that are in the minority in a two-party system would emphasize new policy issues to change dominant party alignment in their favour. In a similar vein, Riker (1996) proposes the term "heresthetics" for the strategy of political parties to introduce a new policy issue to the debate in order to restructure party competition in their favor. More recently, Hobolt and de Vries (2015) have demonstrated that parties that occupy a losing position in a multiparty system would engage in so-called "issue entrepreneurship" by directing attention to a previously ignored policy issue and adopting a position on that issue that is substantially different from the position of their mainstream competitors.

Other scholars have focused on the effects of party type when explaining how the interaction between parties explains issue attention. Meguid (2005, 2008) has focused on the interaction of niche and mainstream parties and has shown that the decision of mainstream parties to emphasize a policy issue is importantly affected by the existence of niche parties which primarily campaign on the issue. Green-Pedersen and Mortensen (2015) moreover demonstrate that mainstream parties are more responsive than niche parties to the common issue agenda of all the other parties in the party system and that political parties are more likely to respond to the issue priorities of parties from their own party family. Finally, Green-Pedersen and Mortensen (2010) focused on the interaction between government and opposition parties. They have demonstrated that opposition parties enjoy more freedom in their choice of policy issues and that they continuously emphasize policy issues which are advantageous to them. By contrast, government parties are primarily driven by the issue priorities of opposition parties which can challenge incumbents on their favourable issues.

While these studies have shed important light on the question why parties emphasize specific policy issues, little is however known about how selective issue emphasis works in coalition governments. Most European countries are governed by coalition cabinets that are composed of at least two different parties that share executive offices. Governing in coalitions has important consequences for political parties as they cannot single-handedly promote their own policy agenda when governing together with other partners. In order to avoid intra-cabinet conflicts and early cabinet breakdown, coalition parties need to coordinate their activities with their partners (Müller and Strøm, 2000, Strøm, Müller and Bergman, 2008). Coalition compromise and cabinet stability does however not come without costs as voters have a hard time identifying the specific policy profiles of political parties that govern together in a cabinet 
Adams, Ezrow and Wlezien, forthcoming, Fortunato and Stevenson, 2013, Fortunato and Adams, 2015

Spoon and Klüver, forthcoming). As a result, coalition parties reconcile the tension between governing in coalitions and competing for voters by coordinating their issue agenda during the middle of the electoral cycle while differentiating from their partners during election campaigns (Sagarzazu and Klüver, forthcoming).

An important piece of the puzzle is however still missing: Who sets the issue agenda and who follows in coalition governments? In this paper we seek to close this important gap in the literature by investigating the dynamics of selective issue emphasis in coalition cabinets. We argue that issue attention in coalition governments is a reciprocal process in which coalition parties respond to each others' issue agendas. Given that governing in coalitions requires unity and compromise to maintain cabinet stability, coalition parties coordinate their activities and talk about the issues that are emphasized by their partners. However, due to the asymmetrical power distribution between senior and junior coalition partners and the important policy prerogatives that come with ministerial portfolios, we expect that junior coalition parties are more responsive to their senior partners than senior partners to their junior partners. Hence, while coalition partners generally follow each other, senior partners enjoy a stronger leadership role in the cabinet.

We test our theoretical expectations based on an innovative study of parties' political communication throughout the entire electoral cycle. We have constructed a novel dataset on parties' issue attention based on a quantitative text analysis of more than 40,000 press releases published by German parties from 2000 until 2010. Using this dataset, we are able to study the dynamics of issue leading and following in coalition governments on a day-to-day basis. Unlike most previous studies of party issue emphasis which were limited to issue competition during election campaigns (Green-Pedersen and Mortensen, 2015: Klüver and Spoon, 2014; Meguid, 2005, 2008; Spoon and Klüver, 2014, 2015; Wagner and Meyer. 2014), we can therefore examine the dynamics of party issue attention throughout the entire electoral cycle. This article moreover makes an important contribution the study of political communication more generally which has devoted a lot of attention to agenda building (see e.g. McCombs, Shaw and Weaver. 1997: Scheufele, 2000), but has not examined how issue agendas are affected by institutional determinants such as coalition governments.

Understanding who sets the issue agenda in coalition governments has major implications for political representation. Political parties play a crucial role for political representation in European democracies. They aggregate and articulate voter preferences and are key actors in the formation and the maintenance of governments in parliamentary systems. Political parties are therefore important intermediary organizations that link voters with political decision-making and thus provide an important channel through which democratic decision-making is legitimized (Dalton, Farrell and McAllister, 2011). It is, however, crucial for political representation that political parties are responsive to voter demands so 
that there is a congruence between what voters want and what political parties do (Miller and Stokes, 1963 Powell, 2000). Since coalition governments are the dominant form of government in European democracies, it is crucial to understand how governing in coalitions affects party responsiveness to their voters. If senior coalition parties for instance constantly dominate the issue agenda while junior coalition parties hardly have a say, governing in coalitions would seriously bias the electoral link between parties and their voters as the issue priorities of supporters of junior partners' would not make it to the issue agenda which might result in voter dissatisfaction and frustration with the government.

The paper proceeds as follows. In the next section, we present our theoretical argument in detail and derive hypotheses that guide the subsequent empirical analysis. Afterwards, we will explain the research design of this study before we illustrate the results of the data analysis. We conclude with a summary of our findings and a discussion of the implications of our results for our understanding of party competition, coalition governments and political representation.

\section{Between following your partners and senior partner dominance}

\section{$2.1 \quad$ Following your partners}

Governing in coalitions requires from coalition partners that they coordinate their activities. Unlike in single-party governments in which governing parties can single-handedly make policy decisions, coalition cabinets are composed of at least two different parties which share executive offices. Even though they join forces to take over governmental responsibility, they have diverging policy preferences which are sometimes difficult to reconcile and may lead to conflicts within the cabinet Strøm and Bergman, 2008). Such disagreements between coalition partners can even result in severe government crises which ultimately lead to an early breakdown of the cabinet (Warwick, 1994, Lupia and Strøm, 1995). In order to avoid intra-cabinet conflicts, coalition parties typically engage in extensive coalition negotiations before they enter governmental offices. Coalition parties bargain about the distribution of ministerial portfolios and a common policy agenda which is frequently written down in formal coalition agreements (Müller, 2008). During their time in office, these agreements serve as a the "coalition bible" (De Winter and Dumont, 2000,322) which guides legislative activity of the cabinet and which coalition parties appeal to in case of intra-party conflicts to remind their partners of the negotiated coalition compromise.

However, the diverging policy preferences of coalition parties entail the constant risk of shirking as coalition parties have incentives to pursue their own policy preferences to reap electoral gains. Shirking is likely if coalition parties can exploit information asymmetries so that their misbehaviour would go 
unnoticed by their partners. In order to prevent such information asymmetries, coalition parties typically install a number of control mechanisms to keep their partners in line (Falcó-Gimeno, 2014 Müller and Meyer, 2010). For instance, coalition partners frequently assign junior ministers from one coalition party to ministries lead by another coalition party to monitor what is going on in portfolios that are under the control of a "hostile" minister (Thies, 2001). Similarly, coalition parties often use parliamentary committees to scrutinize the behaviour of their partners (Martin and Vanberg, 2011).

Given the inherent risk of intra-cabinet conflict which may ultimately lead to early cabinet breakdown, governing in coalitions is typically characterized by compromise and coordination ensured by a diverse set of control mechanisms (Strøm and Bergman, 2008). Rather than single-handedly promoting their own policy priorities, coalition parties coordinate their activities to speak with one voice and to maintain cabinet unity. Accordingly, Sagarzazu and Klüver (forthcoming) have shown that coalition parties coordinate their political communication and emphasize similar policy issues in particular during the middle of the electoral cycle. Similarly, Martin (2004) has demonstrated that coalition cabinets prioritize consensual bills supported by all members of the cabinet. Given the important role of compromise and coordination for the stability of coalition cabinets, we therefore expect that coalition parties primarily follow their partners when selecting what issues to talk about. Coalition parties coordinate their common issue agenda at the cabinet level and collectively decide which policy issues to emphasize. Selective issue emphasis in coalition governments is therefore a reciprocal process in which coalition parties respond to each others' issue priorities.

\section{Hypothesis 1:}

The attention that coalition parties pay to policy issues at $t_{0}$ increases with the attention that their coalition partner paid to this issue at $t_{-1}$.

\subsection{The dominance of senior coalition partners}

Even though coalition cabinets are composed of different coalition parties that are typically needed for a legislative majority, not all coalition parties carry the same weight in the cabinet. The first red-green cabinet under Gerhard Schröder for instance was composed of the social democratic SPD and the Green party. While the SPD managed to obtain 45 per cent of the seats in the German Bundestag, the Green party only controlled 7 per cent of the legislative seats. As a result of this highly asymmetric seat share distribution between the coalition partners, the SPD not only obtained control over the Chancellorship, but it also gained twelve ministerial portfolios while the Green party only received three ministries. The SPD was therefore without doubt the big player in the cabinet which could importantly shape the government agenda. 
The superior role of senior partners in coalition cabinets can be explained by two different factors. First, senior partners enjoy a superior role in the coalition since they control the Prime Ministership. The Prime Minister position provides important advantages to coalition parties as it typically comes with the right to appoint and dismiss individual ministers, the right to decide the jurisdiction of ministerial portfolios and the ability to set the cabinet's agenda (Strøm and Bergman, 2008). Crossman (1972) has accordingly used the term "prime ministerial government" to describe a cabinet type in which the Prime Minister has the ability to decide policy in all domains where the Prime Minister takes an interest, by deciding key issues which subsequently determine the functioning of the cabinet and by deciding the general policy guidelines of the cabinet. The Senior coalition party thus typically holds a superior role in coalition cabinets due to the important procedural and policy powers of the Prime Minister.

Second, senior partners also dominate the coalition since they frequently control considerably more ministries than their junior partners. Senior coalition parties typically managed to win a much higher share of seats in Parliament than their partners. Given that they bring a lot more weight to the bargaining table, senior partners can demand more ministerial portfolios during the coalition negotiations. Accordingly, numerous studies have shown that legislative seat share is proportionally related to the number of ministerial posts coalition parties obtain during government formation (e.g. Gamson, 1961 . Browne and Franklin, 1973; Warwick and Druckman, 2001, 2006, Bäck, Debus and Dumont, 2011). Ministries are an important instrument to shape public policy in a policy area. Coalition parties controlling a ministerial portfolio have important information advantages over their partners as they can draw on the extensive expertise and the resources of the ministerial bureaucracy. They are therefore in a much better position to push forward favoured policies in the policy areas under their jurisdiction. In addition, ministers typically enjoy a certain degree of ministerial autonomy which allows them to make policy decisions in their area of competence without the interference of their partners (Laver and Shepsle, 1996).

Given the superior role of senior coalition parties in the cabinet, we expect that the dynamics of leading and following the issue agenda are importantly conditioned by the status of a coalition party in the cabinet. Senior coalition parties can lead the game due to the important procedural and policy powers of the Prime Minister and the policy agenda-setting powers that come with their considerable number of ministerial portfolios. We therefore expect that even though coalition parties listen to each other when deciding which policy issues to emphasize, junior partners tend to follow their senior partners more given their dominant role in the cabinet.

\section{Hypothesis 2:}

The responsiveness of junior partners to senior partners is higher than the responsiveness of senior 


\section{Research design}

In the following, we will first explain our case selection before we illustrate how we constructed our dependent and independent variables, paying particular attention to the quantitative text analysis used to measure the issue attention of political parties.

\subsection{Political parties in Germany}

Germany provides an ideal setting for the study of issue attention of coalition parties. First, Germany has a long-standing history of coalition politics. Since the reconstruction of Germany after the Second World War, coalition cabinets have been the dominant arrangement for accessing power. As such political parties are used to governing together and are keenly aware of the consequences for electoral competition (Sagarzazu and Klüver, forthcoming). Another important reason for choosing Germany is data availability. German parties represented in the Bundestag (first parliamentary chamber) issue several press releases per day which are publicly accessible. These political texts are ideal to measure policy attention by the parties as parties can freely choose what to communicate to their voters on a daily basis.

\subsection{Measuring issue attention}

Following Klüver and Sagarzazu (2016) and Sagarzazu and Klüver (forthcoming), we measure the issue agenda of political parties in Germany through the press releases made public by their Bundestag party groups. This agenda-setting perspective focuses on the attention given to different policy issues (see for instance Green-Pedersen and Walgrave, 2014). For this purpose press releases are an ideal data source as they provide a continuous stream of party documents to evaluate issue attention on a daily basis. This is a major advantage in contrast to other more static documents such as party manifestos which are only available every four or five years.

The present study includes all press releases available during the period between 2000 until 2010. This period covers four legislative terms with three different government compositions (the SPD and the Greens from 1998 until 2005, a grand-coalition consisting of the CDU/CSU and SPD from 2005 until 2009 and a coalition government between the CDU/CSU and the liberal FDP from 2009 onwards). Our dataset includes all parties with representation in the Bundestag for the period under consideration except for the left-leaning Die Linke. This party was excluded for several reasons. First, it has gone through considerable changes during the period under study. Second, it has not formed part of any 
coalition government. And third, it was not represented as a party group in the Bundestag throughout the entire time period we investigate. ${ }^{2}$ In total our dataset includes over 40,000 press releases (see Table A.2 in the appendix of Sagarzazu and Klüver (forthcoming) for a breakdown of the press releases by year and party) which means that on average parties in Germany publish approximately three press releases per day.

We classify the press releases into issue areas by means of the Bayesian expressed agenda model developed by Grimmer (2010). The Expressed-Agenda Model is an unsupervised algorithm which allows for the identification of topics from press releases based on word co-occurrences within and across the different documents. The expressed agenda model is based on the assumption that topics are expressed with a distinctive set of words (Blei, Ng and Jordan, 2003, Quinn et al., 2010). The model simultaneously identifies topics and classifies the press releases into the respective categories (for further details, see Grimmer, 2010).

Our dataset was prepared following standard procedures in text analysis for converting texts into document term matrices (e.g. Grimmer, 2010, Grimmer and Stewart, 2013). These include deleting all party labels, removing stop words, stemming words to their syntactical root and eliminating frequent (words occurring in more than $95 \%$ of the texts) and infrequent (words occurring in less than $1.5 \%$ of the texts) words. The remaining words are used to create the document term matrix which is required as input for the Expressed Agendas Model. The second input required for the quantitative text analysis is a list of authors per document which corresponds in our case to the parties that issued the press releases. Finally, the expressed agenda model requires the number of issues in which the texts should be classified. We have chosen to estimate the topic model with 20 issue categories. In order to identify the number of issue areas, we followed a two step process. First, we estimated the model with the number of topics varying from 15 to 35 . Second, we assessed the validity of the different topic groupings by: 1) analyzing the internal consistency of words within the topics; 2) comparing the issue classification to the issue agenda of the German Bundestag as structured by its committees; and 3) cross-validating our computer generated measures with the classification performed by human coders. On the basis of the internal consistency check based on key terms per topic, the external cross-validation with the Bundestag committee structure and the cross-validation with manual hand-coding, we are confident that the quantitative text analysis arrived at a reasonable classification of the press releases into issue areas.

Once we finished validating the topics and the classification of press releases into issue areas we proceeded to generate our measures of party issue attention. For each party, we measure the attention that political parties pay to a given issue as the percentage of press releases devoted to the issue of the total number of press releases published by a party in a given month. We do this for all the 20 issues identified by the quantitative text analysis. We use monthly data as we believe this provides the granularity sufficient to 
analyze issue attention by political parties.

\subsection{Measuring explanatory and control variables}

To measure whether coalition parties affect each other with regard to the policy issues that they emphasize, we rely on the lagged issue attention of the coalition partner as the major explanatory variable. More specifically, we explain the attention that senior coalition parties pay to a given policy issue at $t_{0}$ with the attention that the junior partner paid to the policy issue at $t_{-1}$ and vice versa. ${ }^{3}$

In order to test our theoretical expectations, we additionally control for a number of variables which might confound the hypothesized relationship. First, we include a measure of the party's own issue attention to the issue at $\mathrm{t}_{-1}$ as parties may not significantly change their issue agenda from one month to the next. Second, we control for the effect of voter issue attention on parties' issue emphasis. We obtained data on the most important policy issues from the Politbarometer which is a representative survey that is carried out monthly among German citizens and includes an open question that asks respondents about the most important problem (MIP). We matched the most important issues indicated by respondents with the issue areas identified by the text analysis and used the percentage of respondents indicating each issue area as important as a measure for voter issue attention. As political parties need some time to process voters' policy priorities, we predict the emphasis that parties place on a policy issue at $t_{0}$ (the current month) with the salience of the issue among voters at $t_{-1}$ (the past month).

Third, we control for issue ownership of political parties which we operationalize drawing on data on competence attribution obtained from election studies which is a commonly used measure in the literature (see e.g. Bélanger and Meguid, 2008, Green and Hobolt, 2008). We combine two questions included in the German election studies. First, we use the most important problem question included in election studies to identify the issue priorities of German citizens. Second, we use a follow-up question which asks respondents to report which party is most competent in dealing with the most important issue in their view. We rely on the percentage of respondents that indicated that a political party is competent in dealing with a given issue area as a measure for issue ownership of political parties. ${ }^{4}$

Fourth, as issue emphasis might systematically vary over the course of the legislative term, we measure the stage of the electoral cycle by the number of months until the next national election. Fifth, we take into account the impact of state-level elections and European Parliament elections by including dummy variables indicating whether such an election took place during the same month. Sixth, as parties' issue emphasis might furthermore be affected by the attention that other parties pay to policy issues (Adams and Somer-Topcu, 2009: Green-Pedersen and Mortensen, 2010), we control for the lagged attention that opposition parties paid to a policy issue by including a measure for the issue attention of the largest and a 
measure for the issue attention of the smallest opposition party in the model. Seventh, as political parties might place higher emphasis on policy issues which fall into the remits of their ministerial portfolios, we include a dummy variable for ministerial control over the respective issue area. Seventh, we control for cabinet composition by including fixed effects for the three coalition cabinets in office during the time period under investigation. The red-green cabinet serves as reference category. Finally, we control for the effect of election campaigns on coalition parties' issue agenda by including a dummy variable that indicates whether there is an ongoing election campaign period or not. The election campaign dummy is coded 1 in the last three months prior to national elections and 0 otherwise. $^{5}$

\section{Data analysis}

In order to empirically test our hypotheses while controlling for possible confounding variables, we next present multivariate regression models. The observations in our dataset are not independent as assumed by ordinary least squares (OLS) regression. On the one hand, the observations are clustered into twelve issue areas. In order to address this problem, we estimate regression models with clustered robust standard errors that account for this clustering into policy issues. On the other hand, we analyze party issue attention over time as our observations correspond to monthly party issue emphasis from 2000 until 2010. This timing component potentially leads to autocorrelation in the dependent variable. In order to control for potential autocorrelation, we include the lagged dependent variable in the regression analyses (Beck and Katz, 1995, 1996).

TABLE 1 ABOUT HERE 
Table 1 presents the results of the multivariate regression analysis. Model 1 explains issue attention by the senior coalition partner at $t_{0}$ while model 2 explains the attention the junior coalition partner pays to policy issues at $\boldsymbol{t}_{0}$. The coefficients for the lagged junior and the lagged senior partner issue attention respectively in both models exhibit a statistically significant effect on their partners' issue attention. Thus, we find evidence that coalition parties follow each other. The attention that the senior (junior) coalition party in a coalition pays to a policy issue at $t_{0}$ raises with the emphasis that its junior (senior) coalition partner placed on this issue at $t_{-1}$ and vice versa.

We illustrate this relationship in figure 1. The left hand side graph shows the predicted attention by the senior partner at $t_{0}$ to an issue based on the attention of its junior coalition partner to the issue at $t_{-1}$. Likewise, the right hand side figure shows the predicted junior coalition partner's attention to an issue depending on the lagged attention to the issue by its senior coalition partner. These figures were estimated using simulated prediction values as suggested by King, Tomz and Wittenberg (2000). Across the entire range of observed values of coalition parties' issue attention, an increase in the attention by a coalition partner goes hand in hand with an increase in a coalition party's issue emphasis.

\section{FIGURE 1 ABOUT HERE}

Having shown that coalition partners indeed pay attention to what their partners say, we now proceed to see if this relationship is between equals or if there is an imbalance that favours the senior coalition partner. Hypothesis two stated that senior partners should be more influential than junior partners in setting the coalition's agenda due to their superior institutional powers. As can be seen from the coefficients in table 1. both coalition parties listen to each other when deciding what issues to talk about, but the effect of senior parties' issue attention is 0.301 while the effect of junior parties' issue attention is only 0.102 . Hence, both, senior and junior coalition parties respond to each other's issue agenda, but junior parties listen more to their senior counterparts than vice versa. Figure 1 further shows this imbalance in the slope of both curves. An increase in the issue attention by the senior partner at $t_{-1}$ has a considerably stronger effect on the issue attention of its junior partner at $t_{0}$ than the equivalent increase in the attention of the junior partner affects the senior partner's issue agenda.

With regard to the control variables, we only find a statistically significant effect for the attention that opposition parties pay to policy issues. The higher the attention that opposition parties pay to an issue at $t_{-1}$, the larger the emphasis that coalition parties place on this issue at $t_{0}$. Hence, the issue emphasis of coalition parties is amongst others driven by the attention that opposition parties pay to policy issues (Adams and Somer-Topcu, 2009, Green-Pedersen and Mortensen, 2010).

Due to the different pressures that election campaigns exert on incumbent parties (Sagarzazu and Klüver, forthcoming), we conducted a robustness check in which we control for the effect of election campaigns 
on cabinet parties' issue emphasis (see table 22). This model includes a control for press releases published during an election campaign (three months or less before an election) and the interaction between the campaign period and the different measures of coalition partners' issue attention. ${ }^{6}$ As can be seen from the results, the campaign period does not substantively change the dynamics of issue attention between coalition parties. ${ }^{7}$

TABLE 2 ABOUT HERE

\section{Conclusion}

Who sets the issue agenda in coalition cabinets? Even though selective issue emphasis is an important strategy through which political parties compete for voters, we know very little about how the issue agenda is determined in coalition governments. Coalition research has been primarily concerned with studying government formation, cabinet governance and coalition duration (e.g. Bäck, Debus and Dumont, 2011, Müller and Meyer, 2010, Saalfeld, 2008, Strøm and Bergman, 2008) while the question how the issue agenda is determined has largely been neglected so far. In this paper, we have endeavoured to address this important gap in the literature by shedding light on who sets the issue agenda in coalition governments. Based on an analysis of more than 40,000 press releases published by German political parties from 2000 until 2010, we were able to explore the day-to-day dynamics of issue competition between coalition parties. It was demonstrated that issue attention in coalition governments is a reciprocal process in which coalition parties respond to each others' issue agendas. Given that governing in coalitions requires unity and compromise to maintain cabinet stability, coalition parties coordinate their activities and talk about the issues that are emphasized by their partners. However, due to the asymmetrical power distribution between senior and junior coalition partners, we showed that junior coalition parties are more responsive to their senior partners than the other way around. Hence, while coalition partners generally follow each other, senior partners enjoy a stronger leadership role in the cabinet.

Our results have important implications for our understanding of coalition governance and party competition and its consequences for political representation. Governing in coalitions requires coordination and compromise to avoid intra-cabinet conflict and early cabinet dissolution. Thus, unlike parties that govern alone in single-party cabinets, coalition parties cannot independently make policy decisions, but they need to stick to the negotiated coalition compromise. We have shown that coalition parties indeed coordinate their issue priorities as they respond to each other's issue agenda. Coalition parties coordinate their common issue agenda at the cabinet level and collectively decide which policy issues to emphasize. However, due the asymmetric power distribution in coalition cabinets, it is not a 
negotiation process on equal footing in which all coalition parties can similarly affect the common issue agenda. By contrast, we found evidence for a dominating role of the senior coalition partner. While both, senior and junior coalition parties respond to each other's issue attention, junior partners do so to a greater extent.

The findings in this study thus provide further evidence that junior coalition parties are the major losers in coalition cabinets. Junior coalition parties typically receive less ministerial portfolios than their senior counterparts (Browne and Franklin, 1973, Warwick and Druckman, 2001, 2006), voters have a hard time to distinguish them from their senior partners when it comes to their policy profile (Fortunato and Adams, 2015). Our finding that senior coalition parties dominate the issue agenda in coalition cabinets to some extent explains why junior coalition parties struggle electorally. Selective issue emphasis is an important strategy through which parties attract voters (Budge and Farlie, 1983, Ansolabehere and Iyengar, 1994, Petrocik, 1996). By highlighting policy issues that are important for voters or on which parties are considered to be particularly competent, parties can reap significant electoral gains. However, junior coalition parties cannot independently prioritize policy issues that provide electoral benefits as they are constrained by their senior coalition partner which dominates the common issue agenda. Thus, joining a coalition cabinet as a junior partner may be attractive due to the benefits that come with executive offices, but it comes at the expense of losing the autonomy to selectively emphasize favourable policy issues which could explain the significant electoral losses of junior coalition parties.

Finally, our study has important implications for political representation. Citizens delegate the power to make public policy temporarily to political parties who act as their agents (Powell, 2000). Political parties are in turn expected to launch policies on behalf of their voters so that there is congruence between what voters want and what political parties do. However, given that junior coalition parties are importantly constrained by their senior coalition partners which dominate the issue agenda, junior coalition parties cannot effectively perform their representational role. They are not able to respond to all the issue priorities of their voters which may result in disappointed supporters who may turn their back on established parties and instead support populist and extremist parties. Our study has shed important light on why coalition parties choose to talk about some issues and not about others. Even though we only studied coalition parties in Germany, we believe that our findings should travel well to other settings as Germany shares many similarities with other countries such as its parliamentary system, its federalist structure, and its multiparty system. As a result, it is reasonable not to expect dramatically different results in other settings. However, future research should extend the study of coalition parties' issue attention to other political systems as external validity is of course best achieved by comparative research. 


\section{References}

Adams, James, Lawrence Ezrow and Christopher Wlezien. forthcoming. "The Company you keep: How Voters Infer Party Positions on European Integration from Governing Coalition Arrangements." American Journal of Political Science .

Adams, James and Zeynep Somer-Topcu. 2009. "Policy Adjustment by Parties in Response to Rival Parties' Policy Shifts: Spatial Theory and the Dynamics of Party Competition in Twenty-Five Post-War Democracies." British Journal of Political Science 39:825-846.

Andersson, Staffan, Torbjörn Bergman and Svante Ersson. 2012. The European Representative Democracy Data Archive, Release 3. URL (consulted September 2014): www.erdda.se.

Ansolabehere, Stephen and Shanto Iyengar. 1994. "Riding the wave and claiming ownership over issues." Public Opinion Quarterly 58(3):335-357.

Bäck, Hanna, Marc Debus and Patrick Dumont. 2011. "Who gets what in coalition governments? Predictors of portfolio allocation in parliamentary democracies." European Journal of Political Research 50(4):441-478.

Beck, Nathaniel and Jonathan N. Katz. 1995. "What to do (and not to do) with Time-Series Cross-Section Data." American Political Science Review 89(3):634-647.

Beck, Nathaniel and Jonathan N. Katz. 1996. "Nuisance vs. Substance: Specifying and Estimating Time-Series-Cross-Section Models." Political Analysis 6(1):1-36.

Bélanger, Éric and Bonnie M. Meguid. 2008. "Issue salience, issue ownership, and issue-based vote choice." Electoral Studies 27(3):477-491.

Blei, David, Andrew Ng and Michael Jordan. 2003. "Latent dirichlet allocation." Journal of Machine Learning and Research pp. 993-1022.

Browne, Eric C. and Mark N. Franklin. 1973. "Aspects of Coalition Payoffs in European Parliamentary Democracies." American Political Science Review 67(2):453-469.

Budge, I. and D. Farlie. 1983. Explaining and predicting elections: issue effects and party strategies in twenty-three democracies. London: Allen \& Unwin.

Carmines, Edward G. and James A. Stimson. 1986. "On the Structure and Sequence of Issue Evolution." American Political Science Review 80(3):901-920.

Carmines, Edward G. and James A. Stimson. 1989. Issue evolution: Race and the transformation of American Politics. Ithaca: Princeton University Press. 
Crossman, Richard Howard Stafford. 1972. The Myths of Cabinet Government. Cambridge: Harvard University Press.

Dalton, Russell J., David M. Farrell and Ian McAllister. 2011. Political Parties and Democratic Linkage: How Parties Organize Democracy. Oxford: Oxford University Press.

De Winter, Lieven, Arco Timmermans and Patrick Dumont. 2000. Belgium: On government agreements, evangelists, followers and heretics. In Coalition governments in Western Europe, ed. Wolfgang Müller and Kaare Strøm. Oxford University Press pp. 300-355.

Falcó-Gimeno, Albert. 2014. "The use of control mechanisms in coalition governments: The role of preference tangentiality and repeated interactions." Party Politics 20(3):341-356.

Fortunato, David and James Adams. 2015. "How voters' perceptions of junior coalition partners depend on the prime minister's position." European Journal of Political Research 54(3):601-621.

Fortunato, David and Randolph T. Stevenson. 2013. "Perceptions of Partisan Ideologies: The Effect of Coalition Participation." American Journal of Political Science 57(2):459-477.

Gamson, William A. 1961. "A Theory of Coalition Formation." American Sociological Review $26(3): 373-382$.

Green, Jane and Sara B. Hobolt. 2008. "Owning the issue agenda: Party strategies and vote choices in British elections." Electoral Studies 27(3):460-476.

Green-Pedersen, Christoffer and Peter B. Mortensen. 2010. "Who sets the agenda and who responds to it in the Danish parliament? A new model of issue competition and agenda-setting." European Journal of Political Research 49(2):257-281.

Green-Pedersen, Christoffer and Peter B. Mortensen. 2015. "Avoidance and Engagement: Issue Competition in Multiparty Systems." Political Studies 63(4):747-764.

Green-Pedersen, Christoffer and Stefaan Walgrave, eds. 2014. Agenda-Setting, Policies and Political Systems. University of Chicago Press.

Grimmer, Justin. 2010. “A Bayesian Hierarchical Topic Model for Political Texts: Measuring Expressed Agendas in Senate Press Releases." Political Analysis 18(1):1-35.

Grimmer, Justin and Brandon M. Stewart. 2013. "Text as Data: The Promise and Pitfalls of Automatic Content Analysis Methods for Political Texts." Political Analysis .

Hobolt, Sara B. and Catherine E. de Vries. 2015. "Issue Entrepreneurship and Multiparty Competition." Comparative Political Studies 48(9):1159-1185. 
King, Gary, Michael Tomz and Jason Wittenberg. 2000. "Making the most of statistical analyses: Improving interpretation and presentation." American Journal of Political Science 44(2):341-355.

Klüver, Heike and Iñaki Sagarzazu. 2016. "Setting the agenda or responding to voters? Political parties, voters and issue attention." West European Politics 39(2):380-398.

Klüver, Heike and Jae-Jae Spoon. 2014. "Who responds? Voters, parties and issue attention." British Journal of Political Science 46(3):633-654.

Laver, Michael and Kenneth A. Shepsle. 1996. Making and breaking governments: Cabinets and legislatures in parliamentary democracies. Cambridge: Cambridge University Press.

Lupia, Arthur and Kaare Strøm. 1995. "Coalition termination and the strategic timing of legislative elections." American Political Science Review 89(3):648-665.

Martin, Lanny W. and Georg Vanberg. 2011. Parliaments and Coalitions: The Role of Legislative Institutions in Multiparty Governance. Oxford: Oxford University Press.

Martin, Lenny W. 2004. "The Government Agenda in Parliamentary Democracies." American Journal of Political Science 48(3):445-461.

McCombs, Maxwell, Donald L. Shaw and Davis Weaver, eds. 1997. Communication and democracy: Exploring the intellectual frontiers in agenda-setting theory. London: Lawrence Earlbaum.

Meguid, Bonnie M. 2005. "Competition Between Unequals: The Role of Mainstream Party Strategy in Niche Party Success." American Political Science Review 99(3):347-359.

Meguid, Bonnie M. 2008. Party Competition between Unequals: Strategies and Electoral Fortunes in Western Europe. Cambridge: Cambridge University Press.

Miller, Warren E. and Donald E. Stokes. 1963. "Constituency influence in Congress." American Political Science Review 57(1):45-56.

Müller, Wolfgang C. and Thomas M. Meyer. 2010. "Meeting the Challenges of Representation and Accountability in Multi-party Governments." West European Politics 33(5):1065-1092.

Müller, Wolfgang and Kaare Strøm, eds. 2000. Coalition Governments in Western Europe. Oxford: Oxford University Press.

Müller, Wolfgang und Kaare Strøm. 2008. Coalition agreements and cabinet governance. In Cabinets and Coalition Bargaining, ed. Kaare Strøm, Wolfgang C. Müller and Torbjörn Bergman. Oxford University Press pp. 159-199. 
Petrocik, John R. 1996. "Issue Ownership in Presidential Elections, with a 1980 Case Study." American Journal of Political Science 40(3):825-850.

Powell, Bingham G. Jr. 2000. Elections as instruments of democracy: Majoritarian and proportional visions. New Haven: Yale University Press.

Quinn, Kevin M., Burt Monroe, Michael Colaresi, Michael Crespin and Drago Radev. 2010. "How to analyze political attention with minimal assuptions and costs." American Journal of Political Science $54(1): 209-228$.

Riker, William. 1996. The Strategy of Rhetoric: Campaigning for the American Constitution. New Haven: Yale University Press.

Saalfeld, Thomas. 2008. Institutions, Chance and Choices: The Dynamics of Cabinet Survival. In Cabinets and Coalition Bargaining: The Democratic Life Cycle in Western Europe, ed. Kaare Strøm, Wolfgang C. Müller and Torbjörn Bergman. Oxford: Oxford University Press pp. 301-326.

Sagarzazu, Iñaki and Heike Klüver. forthcoming. "Coalition governments and party competition: Political communication strategies of coalition parties." Political Science Research and Methods .

Scheufele, Dietram A. 2000. "Agenda-Setting, Priming, and Framing Revisited: Another Look at Cognitive Effects of Political Communication." Mass Communication and Society 3(2-3):297-316.

Spoon, Jae-Jae and Heike Klüver. 2014. "Do parties respond? How electoral context influences party responsiveness." Electoral Studies 35:48-60.

Spoon, Jae-Jae and Heike Klüver. 2015. "Voter polarization and party responsiveness: Why parties emphasize divided issues, but remain silent on unified issues." European Journal of Political Research $54(2): 343-362$.

Spoon, Jae-Jae and Heike Klüver. forthcoming. "Does Anybody Notice? How Policy Positions of Coalition Parties Are Perceived by Voters." European Journal of Political Research .

Strøm, Kaare, Wolfgang C. Müller and Torbjörn Bergman. 2008. Cabinets and Coalition Bargaining: The Democratic Life Cycle in Western Europe. Oxford: Oxford University Press.

Strøm, Kaare, Wolfgang C. Müller and Torbjörn Bergman, eds. 2008. Cabinets and coalition bargaining: The democractic life cycle in Western Europe. Oxford: Oxford University Press.

Thies, Michael F. 2001. "Keeping Tabs on Partners: The Logic of Delegation in Coalition Governments." American Journal of Political Science 45(3):580-598.

Wagner, Markus and Thomas Meyer. 2014. "Which issues do parties emphasize? Salience strategies and party organisation in multiparty systems." West European Politics 37(5):1019-1045. 
Warwick, Paul. 1994. Government survival in parliamentary democracies. Cambridge: Cambridge University Press.

Warwick, Paul V. and James N. Druckman. 2001. "Portfolio Salience and the Proportionality of Payoffs in Coalition Governments." British Journal of Political Science 31(04):627-649.

Warwick, Paul V. and James N. Druckman. 2006. "The portfolio allocation paradox: An investigation into the nature of a very strong but puzzling relationship." European Journal of Political Research $45(4): 635-665$. 


\section{Notes}

${ }^{1}$ The order of authors follows the principle of rotation. Both authors have contributed equally to all work. Previous versions of this project were presented at the "Dynamics in party communication: political actors and the general public in-between elections", University of Vienna, 2015 and at "The New World of Comparative Political Communication Conference," Texas A\&M University, 2016. We would like to thank the conference participants, Markus Wagner, Thommas Meyer, and Guy D. Whitten for their extremely helpful comments. Direct all correspondence to Iñaki Sagarzazu, Texas Tech University, 10 Holden Hall, Lubbock, TX 79409, inaki.sagarzazu@ttu.edu.

${ }^{2}$ Due to data availability problems, we were not able to include the press releases of the CDU/CSU for 2000.

${ }^{3}$ In all the cabinets we analyzed, there is only one senior coalition partner and one junior coalition partner.

${ }^{4}$ Since the Politbarometer does not regularly include a competence attribution question, it is unfortunately not possible to measure ownership for smaller time intervals. However, since issue ownership is typically a very stable phenomenon, the focus on election studies should not constitute a problem.

${ }^{5}$ We estimated several model specifications varying the length of election campaigns from one to six months. The results remained consistent.

${ }^{6}$ We estimated additional regression models with different length specifications for the campaign length varying from one month to six months prior to a national election. We did not find a systematic effect in any of the model specifications.

${ }^{7}$ We ran a similar model controlling for the honeymoon period and the results remain unchanged. 
Table 1: Multivariate regression analysis of Party Issue Attention

\begin{tabular}{lrr}
\hline DV: Issue attention & $\begin{array}{c}\text { Model 1 } \\
\text { partner }\end{array}$ & $\begin{array}{c}\text { Model 2 } \\
\text { Junior }\end{array}$ \\
partner
\end{tabular}


Table 2: Campaign robustness check regression analysis

\begin{tabular}{|c|c|c|}
\hline DV: Issue attention & $\begin{array}{l}\text { Model } 3 \\
\text { Senior partner }\end{array}$ & $\begin{array}{c}\text { Model } 4 \\
\text { Junior partner }\end{array}$ \\
\hline \multicolumn{3}{|l|}{ Explanatory variables } \\
\hline Junior partner issue attention $(t-1)$ & $\begin{array}{r}0.098^{* *} \\
(0.03)\end{array}$ & \\
\hline Campaign $\times$ Junior partner issue attention $(t-1)$ & $\begin{array}{r}0.128 \\
(0.11)\end{array}$ & \\
\hline Senior partner issue attention $(t-1)$ & & $\begin{array}{r}0.300^{* * *} \\
(0.04)\end{array}$ \\
\hline Campaign $\times$ Senior partner issue attention $(t-1)$ & & $\begin{array}{r}-0.106 \\
(0.20)\end{array}$ \\
\hline Party issue attention $(t-1)$ & $\begin{array}{r}0.394^{* * *} \\
(0.04)\end{array}$ & $\begin{array}{r}0.198^{* *} \\
(0.07)\end{array}$ \\
\hline Campaign $\times$ Party issue attention $(t-1)$ & $\begin{array}{r}0.165^{*} \\
(0.08)\end{array}$ & $\begin{array}{r}0.283^{* *} \\
(0.12)\end{array}$ \\
\hline \multicolumn{3}{|l|}{ Control variables } \\
\hline SPD-CDU Coalition & $\begin{array}{r}0.130 \\
(0.63)\end{array}$ & $\begin{aligned}-0.136 \\
(0.69)\end{aligned}$ \\
\hline CDU-FDP Coalition & $\begin{array}{r}-0.084 \\
(0.52)\end{array}$ & $\begin{aligned}-0.175 \\
(0.54)\end{aligned}$ \\
\hline Voter issue attention $(t-1)$ & $\begin{array}{r}0.062 \\
(0.07)\end{array}$ & $\begin{array}{l}0.017 \\
(0.07)\end{array}$ \\
\hline Competence attribution (Ownership) & $\begin{array}{r}0.005 \\
(0.01)\end{array}$ & $\begin{array}{r}0.001 \\
(0.01)\end{array}$ \\
\hline Ministry control & $\begin{array}{r}0.066 \\
(0.58)\end{array}$ & $\begin{array}{r}0.012 \\
(0.55)\end{array}$ \\
\hline Campaign & $\begin{array}{r}-2.539^{* *} \\
(1.15)\end{array}$ & $\begin{aligned}-1.592 \\
(1.23)\end{aligned}$ \\
\hline EP election & $\begin{array}{r}0.001 \\
(0.55)\end{array}$ & $\begin{aligned}-0.025 \\
(0.73)\end{aligned}$ \\
\hline Regional election & $\begin{array}{r}-0.050 \\
(0.16)\end{array}$ & $\begin{array}{l}-0.057 \\
(0.37)\end{array}$ \\
\hline Largest opposition party issue attention $(t-1)$ & $\begin{array}{r}0.065^{* * *} \\
(0.01)\end{array}$ & $\begin{array}{r}0.092^{* *} \\
(0.03)\end{array}$ \\
\hline Smallest opposition party issue attention $(t-1)$ & $\begin{array}{r}0.107^{* * *} \\
(0.03)\end{array}$ & $\begin{array}{r}0.172^{*} \\
(0.09)\end{array}$ \\
\hline Constant & $\begin{array}{r}2.249^{* * *} \\
(1.03) \\
\end{array}$ & $\begin{array}{r}2.040^{*} \\
(0.98) \\
\end{array}$ \\
\hline $\mathrm{N}$ & 1535.000 & 1490.000 \\
\hline LogLik & -4453 & -4817 \\
\hline R-sqr & 0.455 & 0.354 \\
\hline AIC & 8927.907 & 9655.743 \\
\hline
\end{tabular}


Figure 1: Predicted issue attention by Senior (left) and Junior (right) coalition partner based on their partner's previous issue attention 